\title{
Synthesis of $\left[{ }^{11} \mathrm{C}\right] \mathrm{GSK} 1482160$ as a new PET agent for targeting $\mathrm{P}_{2} \mathrm{X}_{7}$ receptor
}

\author{
Mingzhang Gao, Min Wang, Mark A. Green, Gary D. Hutchins, Qi-Huang Zheng* \\ Department of Radiology and Imaging Sciences, Indiana University School of Medicine, 1345 West $16^{\text {th }}$ Street, Room 202, \\ Indianapolis, IN 46202, USA \\ *Corresponding author. Tel.: +1 317-278-4671. Fax: +1 317-278-9711. E-mail address: qzheng@iupui.edu.
}

This is where the receipt/accepted dates will go; Received Month XX, 2015; Accepted Month XX, 2015 [BMCL RECEIPT]

\begin{abstract}
The authentic standards GSK1482160 and its isomer, as well as the radiolabeling precursors desmethyl-GSK1482160 and Boc-protected desmethyl-GSK1482160 were synthesized from $L$-pyroglutamic acid, methyl $L$-pyroglutamate and 2-chloro-3(trifluoromethyl)benzylamine with overall chemical yield $27-28 \%$ in 3 steps, 58\% in 4 steps, $76 \%$ in 1 step and $33 \%$ in 2 steps, respectively. [ $\left.{ }^{11} \mathrm{C}\right] \mathrm{GSK} 1482160$ was prepared from either desmethyl-GSK1482160 or Boc-protected desmethyl-GSK1482160 with $\left[{ }^{11} \mathrm{C}_{\mathrm{CH}_{3}} \mathrm{OTf}\right.$ through $\mathrm{N}-\left[{ }^{11} \mathrm{C}\right]$ methylation and isolated by HPLC combined with SPE in 40-50\% and 30-40\% radiochemical yield, respectively, based on $\left[{ }^{11} \mathrm{C}\right] \mathrm{CO}_{2}$ and decay corrected to end of bombardment (EOB). The radiochemical purity was >99\%, and the specific activity at EOB was $370-1110 \mathrm{GBq} / \mu \mathrm{mol}$ with a total synthesis time of $\sim 40$-minutes from EOB.
\end{abstract}

Keywords: $\quad\left[{ }^{11}\right.$ C]GSK1482160; Radiosynthesis; Positron emission tomography (PET); P2X $\mathrm{X}_{7}$ receptor; Neuroinflammation.

The purinergic receptor $\mathrm{P} 2 \mathrm{X}$ ligand-gated ion chanel type 7 ( $\mathrm{P} 2 \mathrm{X}_{7}$ receptor) is an adenosine triphosphate (ATP)-gated ion-channel. It is found in the immune, peripheral, and central nervous systems; implicated in ATP-mediated cell death, regulation of receptor trafficking and inflammation; and associated with various cancer, neurological and cardiovascular disorders. ${ }^{1-4}$ Neuroinflammation is considered to play an important role in a variety of neuropathologies, such as Alzheimer's disease, Parkinson's disease and traumatic brain injury. ${ }^{5-7} \mathrm{P}_{2} \mathrm{X}_{7}$ receptor antagonists have been developed as potential pharmaceuticals for the treatment of various diseases including neuroinflammation. ${ }^{8-10}$

We are interested in biomedical imaging to detect and quantify neuroinflammation, with positron emission tomography (PET) offering the best opportunity for success with development and validation of suitable targeted radioligands. However, an ideal PET radiopharmaceutical is still missing. ${ }^{11,12}$ Like others, we have used $\left[{ }^{11} \mathrm{C}\right] \mathrm{PBR} 28-\mathrm{PET}$ (Figure 1) to image neuroinflammation, targeting the $18-\mathrm{kDa}$ translocator protein (TSPO) formerly named the peripheral benzodiazepine receptor (PBR). ${ }^{13,14}$ However, the limitations ${ }^{15,16}$ of $\left[{ }^{11} \mathrm{C}\right]$ PBR28-PET such as low receptor binding, high inter-subject variability in binding affinity, and nonspecific binding in the human brain, due to TSPO polymorphism, have motivated us to search for new molecular targets and PET radioligands.

Increasing evidence suggests the $\mathrm{P} 2 \mathrm{X}_{7}$ receptor as an interesting neuroinflammation-associated molecular target. ${ }^{12,17}$ Recently the synthesis and initial preclinical evaluation of a $\mathrm{P} 2 \mathrm{X}_{7}$ receptor radioligand $\left[{ }^{11} \mathrm{C}\right] \mathrm{A}$ 740003 (racemic compounds, Figure 1) have been reported, but it showed little uptake in brain in healthy male Wistar rats. ${ }^{12}$ We have instead initially focused on GSK1482160 (a chiral compound, $(S)-N$-(2-chloro-3(trifluoromethyl)benzyl)-1-methyl-5-oxopyrrolidine-2carboxamide, 3). Originally developed by GlaxoSmithKline, GSK1482160 is a potent $\mathrm{P}_{2} \mathrm{X}_{7}$ antagonist with excellent biological activity $\left\{\mathrm{PIC}_{50} 8.5\right.$

This is the author's manuscript of the article published in final edited form as:

Gao, M., Wang, M., Green, M. A., Hutchins, G. D., \& Zheng, Q. H. (2015). Synthesis of [11 C] GSK1482160 as a new PET agent for targeting P2X 7 receptor. Bioorganic \& medicinal chemistry letters, 25(9), 1965-1970.

http://dx.doi.org/10.1016/j.bmcl.2015.03.021 
$\left(\mathrm{IC}_{50} 3 \mathrm{nM}\right.$ ) for human $\mathrm{P} 2 \mathrm{X}_{7}$, and $\mathrm{PIC}_{50} 6.6$ for rat $\left.\mathrm{P}_{2} \mathrm{X}_{7}\right\} .{ }^{18-20}$ This compound readily crosses the bloodbrain barrier (BBB), and has been evaluated as a therapeutic agent in a Phase 1 human study, ${ }^{18-20}$ making it an attractive candidate for possible translation to a PET diagnostic agent.

Here we report the synthesis of $\left[{ }^{11} \mathrm{C}\right] \mathrm{GSK} 1482160\{(S)$ $N$-(2-chloro-3-(trifluoromethyl)benzyl)-1-[ $\left[{ }^{11} \mathrm{C}\right]$ methyl5-oxopyrrolidine-2-carboxamide, $\left.\left[{ }^{11} \mathrm{C}\right] 3\right\}$ as a new candidate $\mathrm{PET}$ agent for imaging of $\mathrm{P} 2 \mathrm{X}_{7}$ receptor.

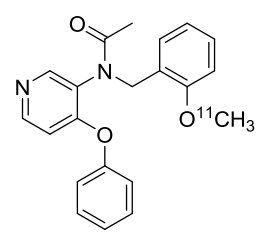

[ $\left.{ }^{11} \mathrm{C}\right] \mathrm{PBR} 28$

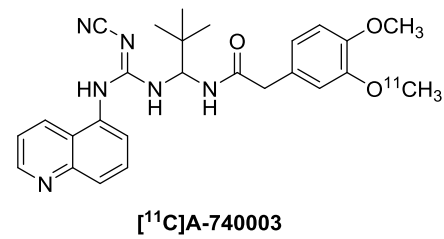

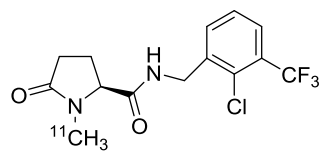

[11 C]GSK1482160

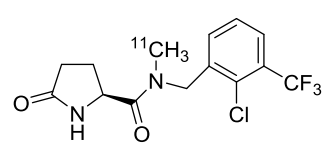

$\left[{ }^{11} \mathrm{C}\right] \mathrm{GSK} 1482160$ isomer
Figure 1. Chemical structures of $\left[{ }^{11} \mathrm{C}\right] \mathrm{PBR} 28, \quad\left[{ }^{11} \mathrm{C}\right] \mathrm{A}-740003$, $\left[{ }^{11} \mathrm{C}\right] \mathrm{GSK} 1482160$, and $\left[{ }^{11} \mathrm{C}\right] \mathrm{GSK} 1482160$ isomer

The reference standard GSK1482160 was synthesized as shown in Scheme 1. ${ }^{18,19} L$-Pyroglutamic acid or methyl $L$-pyroglutamate was reacted with methyl iodide $\left(\mathrm{CH}_{3} \mathrm{I}\right)$ and $\mathrm{NaH}$ in $\mathrm{N}, \mathrm{N}$-dimethylformamide (DMF) to convert into methyl $(S)$-1-methyl-5-oxopyrrolidine-2carboxylate (1) in $41-43 \%$ yield. Subsequently, compound 1 was de-esterified with $\mathrm{NaOH}$ to give $(S)-1$ methyl-5-oxopyrrolidine-2-carboxylic acid (2) in 82\% yield. Then compound 2 underwent a coupling reaction with 2-chloro-3-(trifluoromethyl)benzylamine, using 2ethoxy-1-ethoxycarbonyl-1,2-dihydroquinoline (EEDQ) or 1-ethyl-3-(3-dimethylaminopropyl)carbodimide (EDAC) as catalyst, affording standard compound $\mathbf{3}$ in $80 \%$ yield.
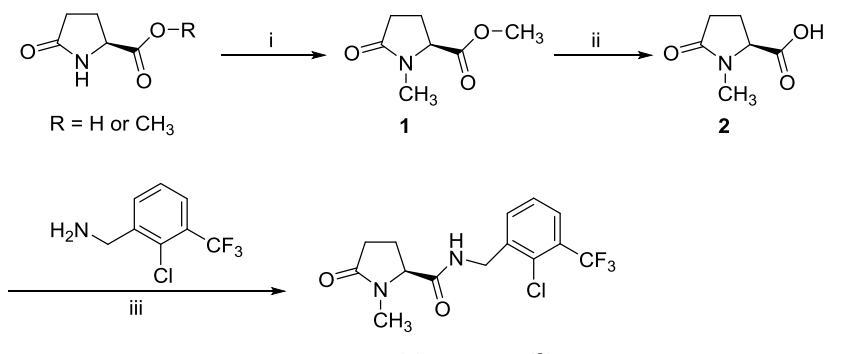

GSK1482160 (3)

Scheme 1. Synthesis of GSK1482160. Reagents, conditions and yields: (i) $\mathrm{NaH}, \mathrm{CH}_{3} \mathrm{I}, \mathrm{DMF}, 0{ }^{\circ} \mathrm{C}$ to RT, 5 h; $41-43 \%$. (ii) $2 \mathrm{M} \mathrm{NaOH}, \mathrm{MeOH}$, reflux, $3 \mathrm{~h} ; 82 \%$. (iii) EEDQ, $\mathrm{CH}_{2} \mathrm{Cl}_{2}$, RT, $15 \mathrm{~h} ; 80 \%$.

The radiolabeling precursors desmethyl-GSK1482160 $\{(S)-N$-(2-chloro-3-(trifluoromethyl)benzyl)-5- oxopyrrolidine-2-carboxamide, 4$\}$ and Boc-protected desmethyl-GSK1482160 (tert-butyl (S)-(2-chloro-3(trifluoromethyl)benzyl)(5-oxopyrrolidine-2-

carbonyl)carbamate, 5), were synthesized as indicated in Scheme 2. The precursor desmethyl-GSK1482160 was prepared from $L$-pyroglutamic acid and 2-chloro-3(trifluoromethyl)benzylamine, with EDAC and 1hydrobenzotrizole (HOBt) as catalysts, ${ }^{21}$ in $76 \%$ yield. The alternative radiochemistry precursor, Boc-protected desmethyl-GSK1482160, was prepared from desmethylGSK1482160 with di-tert-butyl-dicarbonate $\left\{(\mathrm{Boc})_{2} \mathrm{O}\right\}$ using base catalyst 4-dimethylaminopyridine (DMAP) ${ }^{22}$ in acetonitrile in $44 \%$ yield.

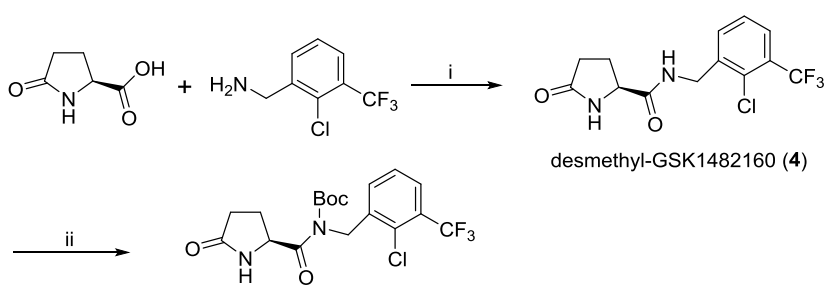

Boc-protected desmethyl-GSK1482160 (5)

Scheme 2. Synthesis of desmethyl-GSK1482160 and Boc-protected desmethyl-GSK1482160. Reagents, conditions and yields: (i) EDAC, $\mathrm{HOBt}$, DCM, RT, 15 h; 76\%; (ii) (Boc) ${ }_{2} \mathrm{O}, \mathrm{Et}_{3} \mathrm{~N}$, DMAP, $\mathrm{CH}_{3} \mathrm{CN}, \mathrm{RT}, 15$ $\mathrm{h} ; 44 \%$.

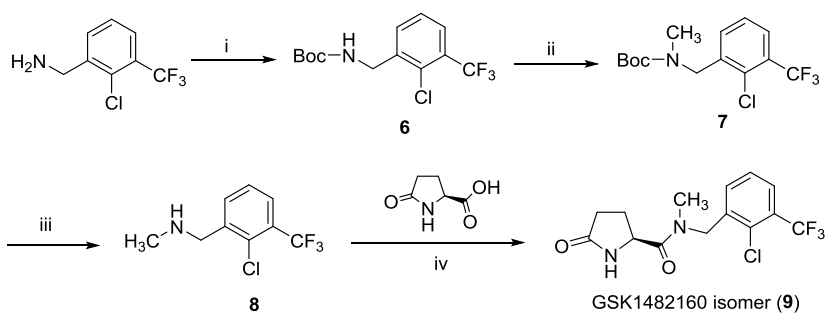

Scheme 3. Synthesis of GSK1482160 isomer. Reagents, conditions and yields: (i) (Boc) $)_{2} \mathrm{O}, \mathrm{THF} / \mathrm{H}_{2} \mathrm{O}$; 90\%. (ii) $\mathrm{NaH}, \mathrm{CH}_{3} \mathrm{I}, \mathrm{THF} ; 91 \%$. (iii) THA, $\mathrm{CH}_{2} \mathrm{Cl}_{2}$, RT, 3 h; $91 \%$. (iv) EEDQ, $\mathrm{CH}_{2} \mathrm{Cl}_{2}$, RT, 15 h; $78 \%$.

As a reference compound, the GSK1482160 isomer (S)$N$-(2-chloro-3-(trifluoromethyl)benzyl)- $N$-methyl-5-

oxopyrrolidine-2-carboxamide (9) was synthesized as outlined in Scheme 3. 2-Chloro-3(trifluoromethyl)benzylamine was reacted with (Boc) ${ }_{2} \mathrm{O}$ in THF and water (1:1) without catalyst to give Bocprotected tert-butyl (2-chloro-3(trifluoromethyl)benzyl)carbamate (6) in $90 \%$ yield. Subsequently compound 6 was methylated with $\mathrm{CH}_{3} \mathrm{I}$ and $\mathrm{NaH}$ to afford tert-butyl (2-chloro-3(trifluoromethyl)benzyl)(methyl)carbamate (7) in $91 \%$ yield. Compound 7 was deprotected with trifluoroacetic acid (TFA) in $\mathrm{CH}_{2} \mathrm{Cl}_{2}$ to obtain 1-(2-chloro-3(trifluoromethyl)phenyl)- $N$-methylmethanamine (8) in $91 \%$ yield. Then compound $\mathbf{8}$ was reacted with $L$ pyroglutamic acid using similar synthetic method for standard compound 3 to produce GSK1482160 isomer in $78 \%$ yield. The ${ }^{1} \mathrm{H}$ NMR spectra of compound 9 showed it contained two epimers, since the methyl 
group is located at the side chain amide. This steric factor does not apply to compound $\mathbf{5}$. Compound $\mathbf{9}$ was formed by the coupling reaction from two different reaction directions, which gave two epimers. The reaction mechanism for synthesis of compound $\mathbf{5}$ is the substitution reaction of amide; in addition, Boc is a bulky group, thus compound $\mathbf{5}$ was formed through a preferential reaction direction, and no epimers were seen in its ${ }^{1} \mathrm{H}$ NMR spectra.

Synthesis of $\left[{ }^{11} \mathrm{C}\right] \mathrm{GSK} 1482160$ via the desmethylGSK1482160 precursor is presented in Scheme 4. Precursor 4 underwent $N-\left[{ }^{11} \mathrm{C}\right]$ methylation ${ }^{23-26}$ using the reactive $\left[{ }^{11} \mathrm{C}\right]$ methylating agent $\left[{ }^{11} \mathrm{C}\right]$ methyl triflate $\left(\left[{ }^{11} \mathrm{C}\right] \mathrm{CH}_{3} \mathrm{OTf}\right)^{27,28}$ in acetonitrile at $80{ }^{\circ} \mathrm{C}$ under basic conditions $(\mathrm{NaH})$ The product was isolated by semipreparative reverse-phase (RP) high performance liquid chromatography (HPLC) with a C-18 column, and then concentrated by solid-phase extraction (SPE) with a disposable C-18 Plus Sep-Pak cartridge ${ }^{29-31}$ to produce the corresponding pure radiolabeled compound $\left[{ }^{11} \mathrm{C}\right] \mathbf{3}$ in $40-50 \%$ radiochemical yield, decay corrected to end of bombardment (EOB), based on $\left[{ }^{11} \mathrm{C}^{-} \mathrm{CO}_{2}\right.$. This is a 1pot-1-step radiosynthesis.

The desmethyl-GSK1482160 precursor contains both cyclic amide and side chain amide. Although the cyclic amide is more easily deprotonated and methylated than side chain amide, a minor by-product $\left[{ }^{11} \mathrm{C}\right]$ GSK1482160 isomer $\quad(S)-N-(2$-chloro-3(trifluoromethyl)benzyl)- $N-\left[{ }^{11} \mathrm{C}\right]$ methyl-5-

oxopyrrolidine-2-carboxamide $\left(\left[{ }^{11} \mathrm{C}\right] \mathbf{9}\right)$ was formed as well. The $\left[{ }^{11} \mathrm{C}\right]$ GSK1482160 and $\left[{ }^{11} \mathrm{C}\right] \mathrm{GSK} 1482160$ isomer were formed in a 10:1 ratio from desmethylGSK1482160. Different solid bases, such as $\mathrm{NaOH}$, $\mathrm{KOH}, \mathrm{K}_{2} \mathrm{CO}_{3}, \mathrm{Cs}_{2} \mathrm{CO}_{3}$ and $\mathrm{NaH}$, were tested in the radiolabeling reaction, and $\mathrm{NaH}$ proved to be the best base for the $N-\left[{ }^{11} \mathrm{C}\right]$ methylation of cyclic amide.

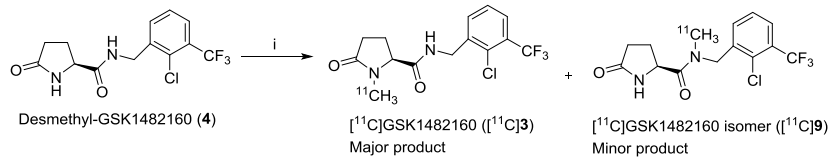

Scheme 4. Synthesis of $\left[{ }^{11} \mathrm{C}\right] \mathrm{GSK} 1482160$ via precursor desmethylGSK1482160. Reagents, conditions and yields: (i) $\left[{ }^{11} \mathrm{C}^{-C_{3}} \mathrm{CH}_{3} \mathrm{OTf}, \mathrm{CH}_{3} \mathrm{CN}\right.$, $\mathrm{NaH}, 80{ }^{\circ} \mathrm{C}, 3 \mathrm{~min} ; 40-50 \%$.

The synthesis of $\left[{ }^{11} \mathrm{C}\right] \mathrm{GSK} 1482160$ via Boc-protected desmethyl-GSK1482160 is outlined in Scheme 5. The precursor 5 was labeled by $\left[{ }^{11} \mathrm{C}_{\mathrm{C}} \mathrm{CH}_{3} \mathrm{OTf}\right.$ through $\mathrm{N}$ $\left[{ }^{11} \mathrm{C}\right]$ methylation in dimethyl sulfoxide (DMSO) at 100 ${ }^{\circ} \mathrm{C}$ under basic condition $\left(\mathrm{K}_{2} \mathrm{CO}_{3}\right)$ to give a radiolabeled intermediate Boc-protected $\left[{ }^{11} \mathrm{C}\right] \mathrm{GSK} 1482160$. This was followed by a quick deprotection reaction with $1 \mathrm{M}$ $\mathrm{HCl}$, without isolation, to provide the target tracer. The radiolabeling mixture was isolated by RP-HPLC combined with SPE to produce the corresponding pure radiolabeled compound $\left[{ }^{11} \mathrm{C}\right] \mathbf{3}$ in $30-40 \%$ decaycorrected radiochemical yield. This is a 1-pot-2-step radiosynthesis. ${ }^{22}$ The best base for the radiolabeling reaction was freshly ground $\mathrm{K}_{2} \mathrm{CO}_{3}$ powder.

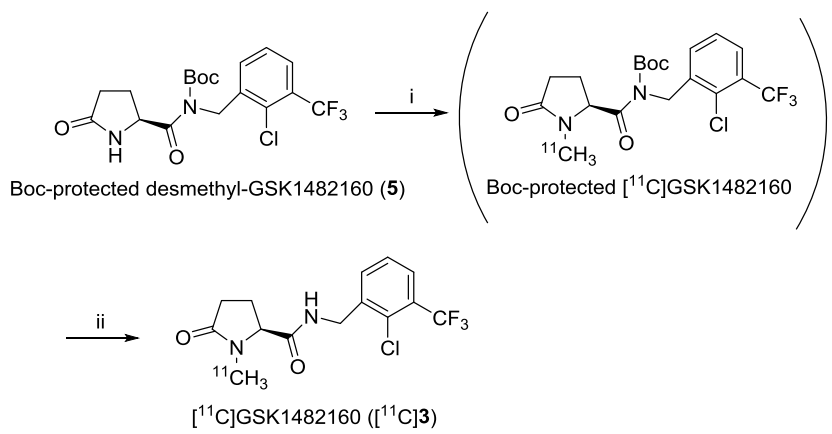

Scheme 5. Synthesis of $\left[{ }^{11} \mathrm{C}\right]$ GSK1482160 via precursor BOC-protected desmethyl-GSK1482160. Reagents, conditions and yields: (i) $\left[{ }^{11} \mathrm{C}_{\mathrm{CH}_{3} \mathrm{OTf}}\right.$, DMSO, $\mathrm{K}_{2} \mathrm{CO}_{3}, 100{ }^{\circ} \mathrm{C}, 5 \mathrm{~min}$; (ii) $1 \mathrm{M} \mathrm{HCl}, 100{ }^{\circ} \mathrm{C}, 3$ $\min ; 30-40 \%$.

Our approach employed more reactive $\left[{ }^{11} \mathrm{C} \mathrm{CH}_{3} \mathrm{OTf}\right.$, instead of commonly used $\left[{ }^{11} \mathrm{C}\right]$ methyl iodide $\left(\left[{ }^{11} \mathrm{C}\right] \mathrm{CH}_{3} \mathrm{I}\right),{ }^{32}$ in $\left[{ }^{11} \mathrm{C}\right]$ methylation of the amide, and thus the radiochemical yield of $\left[{ }^{11} \mathrm{C}\right] \mathbf{3}$ was relatively high. It is important to note that the strong base $\mathrm{NaH}$ would help the $N-\left[{ }^{11} \mathrm{C}\right]$ methylation of unprotected amide precursor desmethyl-GSK1482160, and significantly increase the radiochemical yield of $\left[{ }^{11} \mathrm{C}\right] \mathbf{3}$. Therefore, the radiochemical yields for $\left[{ }^{11} \mathrm{C}\right] 3$ reported here are much higher than that the $N-\left[{ }^{11} \mathrm{C}\right]$ methylation of amide precursor with other base $(\mathrm{KOH})$ reported previously. ${ }^{25}$ For the Boc-protected desmethylGSK1482160 precursor, it was better to conduct the $\mathrm{N}$ $\left[{ }^{11} \mathrm{C}\right]$ methylation of amide under mildly basic conditions $\left(\mathrm{K}_{2} \mathrm{CO}_{3}\right)$, since the Boc protecting group is not very stable under strongly basic conditions with high reaction temperature. Only a relatively small amount of the precursor $(0.3-0.5 \mathrm{mg})$ was used for radiolabeling, instead of our more commonly used amount of the precursor (1.0-1.5 mg), which improved the chemical purity of the final tracer solution. Furthermore, addition of $\mathrm{NaHCO}_{3}$ solution to quench the radiolabeling reaction and to dilute the radiolabeling mixture prior to the injection onto the semi-preparative HPLC column for purification, gave better separation of $\left[{ }^{11} \mathrm{C}\right] \mathbf{3}$ from its unprotected or protected amide precursor $(\mathbf{4}$ or $\mathbf{5}) .^{29-31,33}$

The radiosynthesis was performed in a home-built automated multi-purpose $\quad\left[{ }^{11} \mathrm{C}\right]$-radiosynthesis module. $^{34-36}$ This radiosynthesis module facilitated the overall design of the reaction, purification and reformulation capabilities in a fashion suitable for adaptation to preparation of human doses. In addition, the module is designed to allow in-process measurement of $\left[{ }^{11} \mathrm{C}\right]$-tracer specific activity (SA, GBq/ $\mu$ mol at EOB) using a radiation detector at the outlet of the HPLC- 
portion of the system. ${ }^{26}$ For the reported syntheses, product SA was in a range of $370-1110 \mathrm{GBq} / \mu \mathrm{mol}$ at EOB.

The factors that affect the EOB SA significantly to lead to such a wide range from 370 to $1110 \mathrm{GBg} / \mu \mathrm{mol}$ are mainly from two parts: (1) carrier from the $\left[{ }^{11} \mathrm{C}\right]$-target, and (2) carrier from the $\left[{ }^{11} \mathrm{C}\right]$-radiosynthesis unit. ${ }^{26} \mathrm{We}$ have optimized the $\left[{ }^{11} \mathrm{C}\right]$ gas irradiation target system and the $\left[{ }^{11} \mathrm{C}\right]$-radiosynthesis unit to eliminate ${ }^{12} \mathrm{C}$ carrier-added as much as possible and to reach the high end of the SA. To help produce high SA $\left[{ }^{11} \mathrm{C}^{-} \mathrm{CO}_{2}\right.$, we usually do 2-3 10-minute target pre-burns, with the same beam current, prior to the actual production run. These pre-burn warm up the cyclotron target and eliminate significant amount of ${ }^{12} \mathrm{C}$ carrier in the cyclotron's $\left[{ }^{11} \mathrm{C}\right]$ gas target. We use an Eckert \& Ziegler Modular Lab C-11 Methyl Iodide/Triflate module to produce $\left[{ }^{11} \mathrm{C}_{\mathrm{CH}_{3} \mathrm{OTf}}\right.$ convenient gas phase bromination of $\left[{ }^{11} \mathrm{C}\right]$ methane, and production of $\left[{ }^{11} \mathrm{C}_{\mathrm{CH}_{3}} \mathrm{OTf}\right.$. This 'dry' method, using $\mathrm{Br}_{2}$ to generate a $\left[{ }^{11} \mathrm{C}\right] \mathrm{CH}_{3} \mathrm{Br}$ intermediate, differs from other 'dry' methods using $\mathrm{I}_{2}$ and 'wet' methods using $\mathrm{LiAlH}_{4}$ and $\mathrm{HI}$, and seems to help minimize introduction of additional ${ }^{12} \mathrm{C}$ carrier after $\left[{ }^{11} \mathrm{C}\right] \mathrm{CO}_{2}$ production. ${ }^{28}$

The 1-pot-1-step radiosynthesis via desmethylGSK1482160 is a non-specific synthesis route, and 1pot-2-step radiosynthesis via Boc-protected desmethylGSK1482160 is a specific synthesis route. The nonspecific route required lower reaction temperature, shorter reaction time, and shorter overall synthesis time. Consequently it gave higher radiochemical yield. In addition, it is easier to synthesize the precursor without Boc group than with Boc group. This route is somewhat simpler to implement as it avoids adding a deprotection step. Fortunately, this route proceeds with high selectivity $(\sim 10: 1)$ for $\left[{ }^{11} \mathrm{C}\right]$ methylation at the $N$ of the desired cyclic amide over the acyclic amide, and the desired product has been cleanly isolated after semipreparative HPLC purification of the radiolabeling reaction mixture. In comparison with these two radiosynthesis approaches, the non-specific route is identified as a more appropriate route for future applications.

Chemical purity and radiochemical purity were determined by analytical HPLC. ${ }^{37}$ The chemical purity of the precursors and reference standards was $>93 \%$. The radiochemical purity of the target tracers was $>99 \%$ determined by radio-HPLC through $\gamma$-ray (PIN diode) flow detector, and the chemical purity of the target tracers was $>90 \%$ determined by reversed-phase HPLC through UV flow detector.
The experimental details and characterization data for compounds $\mathbf{1 - 9}$ and for the tracer $\left[{ }^{11} \mathrm{C}\right] \mathbf{3}$ are given. ${ }^{38}$

In summary, synthetic routes with moderate to excellent yields have been developed to produce the precursors desmethyl-GSK1482160 and Boc-protected desmethylGSK1482160; the reference standards GSK1482160 and GSK1482160 isomer; and the target PET radiotracer $\left[{ }^{11} \mathrm{C}\right] \mathrm{GSK} 1482160$. The radiosynthesis employed $\left[{ }^{11} \mathrm{C}\right] \mathrm{CH}_{3} \mathrm{OTf}$ for $N$ - $\left[{ }^{11} \mathrm{C}\right]$ methylation at the nitrogen position of the amide precursors, followed by product purification and isolation by a semi-preparative RP HPLC combined with solid-phase extraction. The desired $\left[{ }^{11} \mathrm{C}\right]$ GSK1482160 was obtained in high radiochemical yield, radiochemical purity and chemical purity, with a reasonably short overall synthesis time, and high specific activity. This will facilitate studies to evaluate $\left[{ }^{11} \mathrm{C}\right] \mathrm{GSK} 1482160$ as a new PET radiopharmaceutical for targeting the $\mathrm{P} 2 \mathrm{X}_{7}$ receptor in animals and humans.

\section{Acknowledgments}

This work was partially supported by the Indiana University Department of Radiology and Imaging Sciences and Indiana State Department of Health (ISDH) Indiana Spinal Cord \& Brain Injury Fund (ISDH EDS-A70-2-079612) in the United States. ${ }^{1} \mathrm{H}$ NMR and ${ }^{13} \mathrm{C}$ NMR spectra were recorded at 500 and $125 \mathrm{MHz}$, respectively, on a Bruker Avance II $500 \mathrm{MHz}$ NMR spectrometer in the Department of Chemistry and Chemical Biology at Indiana University Purdue University Indianapolis (IUPUI), which is supported by the United States National Science Foundation (NSF) Major Research Instrumentation Program (MRI) grant CHE-0619254.

\section{References and notes}

1. Gever, J. R.; Cockayne, D. A.; Dillon, M. P. Eur. J. Physiol. 2006, 452, 513.

2. Di Virgilio, F. Cancer Res. 2012, 72, 5441.

3. Waszkielewicz, A. M.; Gunia, A.; Szkaradek, N.; Słoczyńska, K.; Krupińska, S.; Marona, H. Curr. Med. Chem. 2013, 20, 1241.

4. Sperlágh, B.; Illes, P. Trends Pharmacol. Sci. 2014, 35, 537.

5. Takeda, S.; Sato, N.; Morishita, R. Front. Aging Neurosci. 2014, 6, 171.

6. Stoessl, A. J.; Lehericy, S.; Strafella, A. P. Lancet 2014, 384, 532.

7. Kabadi, S. V.; Faden, A. I. Neural Regen. Res. 2014, 9, 1578.

8. Chrovian, C. C.; Rech, J. C.; Bhattacharya, A.; Letavic, M. A. Prog. Med. Chem. 2014, 53, 65.

9. Franke, H.; Illes, P. Neurosci. Lett. 2014, 565, 14. 
10. Takenouchi, T.; Sekiyama, K.; Sekigawa, A.; Fujita, M.; Waragai, M.; Sugama, S.; Iwamaru, Y.; Kitani, H.; Hashimoto, M. Arch. Immunol. Ther. Exp. (Warsz) 2010, 58, 91.

11. Gerhard, A. Curr. Neurol. Neurosci. Rep. 2013, 13, 405.

12. Janssen, B.; Vugts, D. J.; Funke, U.; Spaans, A.; Schuit, R. C.; Kooijman, E.; Rongen, M.; Perk, L. R.; Lammertsma, A. A.; Windhorst, A. D. J. Label. Compd. Radiopharm. 2014, 57, 509.

13. Wang, M.; Yoder, K. K.; Gao, M.; Mock, B. H.; Xu, X.-M.; Saykin, A. J.; Hutchins, G. D.; Zheng, Q.-H. Bioorg. Med. Chem. Lett. 2009, 19, 5636.

14. Yoder, K. K.; Nho, K.; Risacher, S. L.; Kim, S.; Shen, L.; Saykin, A. J. J. Nucl. Med. 2013, 54, 1320.

15. Zimmer, E. R.; Leuzy, A.; Benedet, A. L.; Breitner, J.; Gauthier, S.; Rosa-Neto, P. J. Neuroinflammation 2014, 11, 120.

16. Chauveau, F.; Boutin, H.; Van Camp, N.; Dollé, F.; Tavitian, B. Eur. J. Nucl. Med. Mol. Imaging 2008, 35, 2304.

17. Volonté, C.; Apolloni, S.; Skaper, S. D.; Burnstock, G. CNS Neurol. Disord. Drug Targets 2012, 11, 705.

18. Abdi, M. H.; Beswick, P. J.; Billinton, A.; Chambers, L. J.; Charlton, A.; Collins, S. D.; Collis, K. L.; Dean, D. K.; Fonfria, E.; Gleave, R. J.; Gleave, R. L.; Lejeune, C. L.; Livermore, D. G.; Medhurst, S. J.; Michel, A. D.; Moses, A. P.; Page, L.; Patel, S.; Roman, S. A.; Senger, S.; Slingsby, B.; Steadman, J. G. A.; Stevens, A. J.; Walter, D. S. Bioorg. Med. Chem. Lett. 2010, 20, 5080.

19. Abberley, L.; Bebius, A.; Beswick, P. J.; Billinton, A.; Collis, K. L.; Dean, D. K.; Fonfria, E.; Gleave, R. J.; Medhurst, S. J.; Michel, A. D.; Moses, A. P.; Patel, S.; Roman, S. A.; Scoccitti, T.; Smith, B.; Steadman, J. G. A.; Walter, D. S. Bioorg. Med. Chem. Lett. 2010, 20, 6370 .

20. Ali, Z.; Laurijssens, B.; Ostenfeld, T.; McHugh, S.; Stylianou, A.; Scott-Stevens, P.; Hosking, L.; Dewit, O.; Richardson, J. C.; Chen, C. Br. J. Clin. Pharmacol. 2013, 75, 197.

21. Wang, M.; Gao, M.; Miller, K. D.; Zheng, Q.-H. Bioorg. Med. Chem. Lett. 2013, 23, 1017.

22. Gao, M.; Wang, M.; Miller, K. D.; Zheng, Q.-H. Bioorg. Med. Chem. Lett. 2013, 23, 4342.

23. Wang, M.; Gao, M.; Steele, B. L.; Glick-Wilson, B. E.; Brown-Proctor, C.; Shekhar, A.; Hutchins, G. D.; Zheng, Q.-H. Bioorg. Med. Chem. Lett. 2012, 22, 4713.

24. Gao, M.; Shi, Z.; Wang, M.; Zheng, Q.-H. Bioorg. Med. Chem. Lett. 2013, 23, 1953.

25. Wang, M.; Gao, M.; Zheng, Q.-H. Bioorg. Med. Chem. Lett. 2013, 23, 5259.

26. Wang, M.; Gao, M.; Zheng, Q.-H. Bioorg. Med. Chem. Lett. 2014, 24, 4455.

27. Jewett, D. M. Int. J. Radiat. Appl. Instrum. A 1992, 43, 1383.

28. Mock, B. H.; Mulholland, G. K.; Vavrek, M. T. Nucl. Med. Biol. 1999, 26, 467.
29. Gao, M.; Wang, M.; Mock, B. H.; Glick-Wilson, B. E.; Yoder, K. K.; Hutchins, G. D.; Zheng, Q.-H. Appl. Radiat. Isot. 2010, 68, 1079.

30. Wang, M.; Gao, M.; Miller, K. D.; Zheng, Q.-H. Steroids 2011, 76, 1331.

31. Wang, M.; Gao, M.; Miller, K. D.; Sledge, G. W.; Zheng, Q.-H. Bioorg. Med. Chem. Lett. 2012, 22, 1569 .

32. Allard, M.; Fouquet, E.; James, D.; Szlosek-Pinaudm, M. Curr. Med. Chem. 2008, 15, 235.

33. Gao, M.; Wang, M.; Hutchins, G. D.; Zheng, Q.-H. Appl. Radiat. Isot. 2008, 66, 1891.

34. Mock, B. H.; Zheng, Q.-H.; DeGrado, T. R. J. Label. Compd. Radiopharm. 2005, 48, S225.

35. Mock, B. H.; Glick-Wilson, B. E.; Zheng, Q.-H.; DeGrado, T. R. J. Label. Compd. Radiopharm. 2005, 48, S224.

36. Wang, M.; Gao, M.; Zheng, Q.-H. Appl. Radiat. Isot. 2012, 70, 965.

37. Zheng, Q.-H.; Mock, B. H. Biomed. Chromatogr. 2005, 19, 671 .

38. (a) General: All commercial reagents and solvents were purchased from Sigma-Aldrich and Fisher Scientific, and used without further purification. $\left[{ }^{11} \mathrm{C}\right] \mathrm{CH}_{3} \mathrm{OTf}$ was prepared according to a literature procedure. ${ }^{28}$ Melting points were determined on a MEL-TEMP II capillary tube apparatus and were uncorrected. ${ }^{1} \mathrm{H}$ NMR and ${ }^{13} \mathrm{C}$ NMR spectra were recorded at 500 and $125 \mathrm{MHz}$, respectively, on a Bruker Avance II $500 \mathrm{MHz}$ NMR spectrometer using tetramethylsilane (TMS) as an internal standard. Chemical shift data for the proton resonances were reported in parts per million (ppm, $\delta$ scale) relative to internal standard TMS $(\delta 0.0)$, and coupling constants $(J)$ were reported in hertz $(\mathrm{Hz})$. Liquid chromatography-mass spectra (LC-MS) analysis was performed on an Agilent system, consisting of an 1100 series HPLC connected to a diode array detector and a 1946D mass spectrometer configured for positiveion/negative-ion electrospray ionization. The high resolution mass spectra (HRMS) were obtained using a Waters/Micromass LCT Classic spectrometer. Chromatographic solvent proportions are indicated as volume:volume ratio. Thin-layer chromatography (TLC) was run using Analtech silica gel GF uniplates $\left(5 \times 10 \mathrm{~cm}^{2}\right)$. Plates were visualized under UV light. Normal phase flash column chromatography was carried out on EM Science silica gel 60 (230-400 mesh) with a forced flow of the indicated solvent system in the proportions described below. All moisture- and air-sensitive reactions were performed under a positive pressure of nitrogen maintained by a direct line from a nitrogen source. Analytical HPLC was performed using a Prodigy (Phenomenex) $5 \mu \mathrm{m}$ C-18 column, $4.6 \times 250 \mathrm{~mm}$; mobile phase $40 \%$ $\mathrm{CH}_{3} \mathrm{CN} / 60 \% 20 \mathrm{mM} \mathrm{H} \mathrm{PO}_{4}$; flow rate $1.0 \mathrm{~mL} / \mathrm{min}$; and UV (254 nm) and $\gamma$-ray (PIN diode) flow detectors. Semi-preparative HPLC was performed 
using a Prodigy (Phenomenex) $5 \mu \mathrm{m} \mathrm{C}-18$ column, 12 $\mathrm{nm}, 10 \times 250 \mathrm{~mm}$; mobile phase $40 \% \mathrm{CH}_{3} \mathrm{CN} / 60 \%$ $\mathrm{H}_{2} \mathrm{O} ; 5.0 \mathrm{~mL} / \mathrm{min}$ flow rate; $\mathrm{UV}(254 \mathrm{~nm})$ and $\gamma$-ray (PIN diode) flow detectors. C18 Plus Sep-Pak cartridges were obtained from Waters Corporation (Milford, MA). Sterile Millex-FG $0.2 \mu \mathrm{m}$ filter units were obtained from Millipore Corporation (Bedford, MA).

(b) Methyl (S)-1-methyl-5-oxopyrrolidine-2carboxylate (1): Method A (from $L$-pyroglutamic acid). To a stirred suspension of sodium hydride $(60 \%$ dispersion in mineral oil, $2.1 \mathrm{~g}, 52 \mathrm{mmol}$ ) in DMF (60 $\mathrm{mL})$ at $0{ }^{\circ} \mathrm{C}$ under nitrogen, $L$-pyroglutamic acid $(2.58$ $\mathrm{g}, 20 \mathrm{mmol}$ ) was added during $15 \mathrm{~min}$. The mixture was stirred at room temperature (RT) for $1 \mathrm{~h}$. While ice cooling and stirring, iodomethane (7.76 g, 55 mmol) was added and the reaction mixture was allowed to warm to RT overnight. The solvent was evaporated under reduced pressure, and water was added. After $\mathrm{pH}$ was adjust to 5 with adding acetic acid, the aqueous layer was extracted with $\mathrm{CH}_{2} \mathrm{Cl}_{2}$ $(100 \mathrm{~mL} \times 3)$. The organic layer was concentrated, and the residue was purified by column chromatography on silica gel with eluent (30:70 EtOAc/hexanes) to give colorless oily product $\mathbf{1}(1.35$ g, 43\%). $R_{f}=0.68\left(1: 19 \mathrm{MeOH} / \mathrm{CH}_{2} \mathrm{Cl}_{2}\right) .{ }^{1} \mathrm{H} \mathrm{NMR}$ $\left(\mathrm{CDCl}_{3}\right): \delta 2.07-2.09(\mathrm{~m}, 1 \mathrm{H}, \mathrm{CH}), 2.33-2.40(\mathrm{~m}, 2 \mathrm{H}$, $\left.\mathrm{CH}_{2}\right), 2.47-2.49(\mathrm{~m}, 1 \mathrm{H}, \mathrm{CH}), 2.85\left(\mathrm{~s}, 3 \mathrm{H}, \mathrm{NCH}_{3}\right)$, $3.78\left(\mathrm{~s}, 3 \mathrm{H}, \mathrm{OCH}_{3}\right), 4.12(\mathrm{dd}, J=3.0,8.0 \mathrm{~Hz}, 1 \mathrm{H}$, $\mathrm{CH})$. MS (ESI): $158\left([\mathrm{M}+\mathrm{H}]^{+}, 100 \%\right)$. Method B (from methyl $L$-pyroglutamate). Methyl $L$ pyroglutamate $(1.43 \mathrm{~g}, 10 \mathrm{mmol}$ was dissolved in DMF $(25 \mathrm{~mL})$ and cooled to $0{ }^{\circ} \mathrm{C}$. Sodium hydride (60\% suspension in mineral oil, $0.6 \mathrm{~g}, 15 \mathrm{mmol}$ ) was added to the reaction mixture and stirred for $1 \mathrm{~h}$. Then methyl iodide $(2.11 \mathrm{~g}, 15 \mathrm{mmol})$ was added slowly, the mixture was allowed to warm to RT and stirred for another $1 \mathrm{~h}$. The solvent was evaporated in vacuo, and water was added, subsequently acetic acid was added to adjust $\mathrm{pH}$ to 5 , the aqueous layer was then extracted with $\mathrm{CH}_{2} \mathrm{Cl}_{2}(60 \mathrm{~mL} \times 3)$. The organic layer was concentrated, and the residue was purified by column chromatography on silica gel with eluent (30:70 EtOAc/hexanes) to yield colorless oily product 1 (0.64 g, 41\%). Analytical data was identical with Method A.

(c) (S)-1-Methyl-5-oxopyrrolidine-2-carboxylic acid (2): Compound 1 (0.47 g, $3.0 \mathrm{mmol})$ was dissolved in methanol $(20 \mathrm{~mL})$, and to this solution was added $2 \mathrm{M}$ $\mathrm{NaOH}(3 \mathrm{~mL}, 6.0 \mathrm{mmol})$. The mixture was refluxed for $3 \mathrm{~h}$, then cooled and evaporated to leave a minimal amount of water. This mixture was acidified to $\mathrm{pH} 2$ using $1 \mathrm{M}$ aqueous $\mathrm{HCl}$. The aqueous was extracted with $\mathrm{CH}_{2} \mathrm{Cl}_{2}(100 \mathrm{~mL} \times 3)$, and organic layer was washed with water, dried over $\mathrm{MgSO}_{4}$. The solvent was evaporated to afford white solid compound 2 (0.35 g, 82\%). $R_{f}=0.11\left(1: 5 \mathrm{MeOH} / \mathrm{CH}_{2} \mathrm{Cl}_{2}\right), \mathrm{mp}$ 148-150 ${ }^{\circ} \mathrm{C}$. ${ }^{1} \mathrm{H}$ NMR (DMSO-d 6 ): $\delta 1.92-1.94(\mathrm{~m}$, $1 \mathrm{H}, \mathrm{CH}), 2.19-2.30\left(\mathrm{~m}, 3 \mathrm{H}, \mathrm{CH}_{2}\right.$ and $\left.\mathrm{CH}\right), 2.69(\mathrm{~s}, 3 \mathrm{H}$, $\mathrm{NCH}_{3}$ ), 4.11 (dd, $\left.J=3.8,8.8 \mathrm{~Hz}, 1 \mathrm{H}, \mathrm{CH}\right), 12.97$ (s,
1H, COOH). MS (ESI): $309\left([2 \mathrm{M}+\mathrm{Na}]^{+}, 20 \%\right), 287$ $\left([2 \mathrm{M}+\mathrm{H}]^{+}, 100 \%\right), 144\left([\mathrm{M}+\mathrm{H}]^{+}, 60 \%\right)$

(d) (S)-N-(2-Chloro-3-(trifluoromethyl)benzyl)-1methyl-5-oxopyrrolidine-2-carboxamide

(GSK1482160, 3): Compound 2 (286 mg, $2.0 \mathrm{mmol})$ was suspended in $\mathrm{CH}_{2} \mathrm{Cl}_{2}$ (60 mL), and EEDQ (543 $\mathrm{mg}, 2.2 \mathrm{mmol}$ ) was added. The mixture was stirred at RT for $10 \mathrm{~min}$. A solution of 2-chloro-3(trifluoromethyl)benzylamine $(440 \mathrm{mg}, 2.1 \mathrm{mmol}$ ) in $\mathrm{CH}_{2} \mathrm{Cl}_{2}(20 \mathrm{~mL})$ was then added dropwise to the mixture. The mixture was then stirred at RT overnight. The mixture was washed with saturated aqueous $\mathrm{NaHCO}_{3}(40 \mathrm{~mL}), 2 \mathrm{~N}$ aqueous $\mathrm{HCl}(40 \mathrm{~mL} \times 2)$, and water. The organic solution was dried over $\mathrm{Na}_{2} \mathrm{SO}_{4}$, filtered and concentrated in vacuo. The resulting crude product was then purified by column chromatography on silica gel with eluent $\left(2: 98 \mathrm{MeOH} / \mathrm{CH}_{2} \mathrm{Cl}_{2}\right)$ to obtain white solid product $3(534 \mathrm{mg}, 80 \%) . R_{f}=0.53$ (1:12 $\left.\mathrm{MeOH} / \mathrm{CH}_{2} \mathrm{Cl}_{2}\right)$, mp 166-168 ${ }^{\circ} \mathrm{C}$. ${ }^{1} \mathrm{H}$ NMR (acetone- $\left.\mathrm{d}_{6}\right): \delta 1.96-2.03(\mathrm{~m}, 1 \mathrm{H}, \mathrm{CH}), 2.18-2.21(\mathrm{~m}$, $1 \mathrm{H}, \mathrm{CH}), 2.28-2.36\left(\mathrm{~m}, 1 \mathrm{H}, \mathrm{CH}_{2}\right), 2.77\left(\mathrm{~s}, 3 \mathrm{H}, \mathrm{NCH}_{3}\right)$, $4.17(\mathrm{dd}, J=3.5,8.5 \mathrm{~Hz}, 1 \mathrm{H}, \mathrm{CH}), 4.63(\mathrm{~d}, J=6.0 \mathrm{~Hz}$, $\left.2 \mathrm{H}, \mathrm{CH}_{2}\right), 7.55(\mathrm{t}, J=8.0 \mathrm{~Hz}, 1 \mathrm{H}, \mathrm{Ph}-\mathrm{H}), 7.75(\mathrm{t}, J=$ $8.0 \mathrm{~Hz}, 2 \mathrm{H}, \mathrm{Ph}-\mathrm{H}), 8.05$ (br s, 1H, NH). MS (ESI): $335\left([\mathrm{M}+\mathrm{H}]^{+}, 100 \%\right)$; MS (ESI): $333\left([\mathrm{M}-\mathrm{H}]^{-}, 50 \%\right)$.

(e) (S)-N-(2-Chloro-3-(trifluoromethyl)benzyl)-5oxopyrrolidine-2-carboxamide (desmethylGSK1482160, 4): L-Pyroglutamic acid (516 mg, 4.0 mmol) and 2-chloro-3-(trifluoromethyl)benzylamine (838 mg, $4.0 \mathrm{mmol})$ were mixed with EDAC $\mathrm{HCl}(959$ $\mathrm{mg}, 5.0 \mathrm{mmol})$ and $\mathrm{HOBt}(676 \mathrm{mg}, 5.0 \mathrm{mmol})$ in dry $\mathrm{CH}_{2} \mathrm{Cl}_{2}(100 \mathrm{~mL})$. The reaction mixture was stirred at RT for overnight. Then the resultant mixture was washed with $2 \mathrm{~N} \mathrm{HCl}(50 \mathrm{~mL} \times 3)$ and saturated aqueous $\mathrm{NaHCO}_{3}(40 \mathrm{~mL})$. The organic layer was dried over $\mathrm{Na}_{2} \mathrm{SO}_{4}$ and concentrated. The residue was purified by column chromatography on silica gel with eluent $\left(2: 98 \mathrm{MeOH} / \mathrm{CH}_{2} \mathrm{Cl}_{2}\right)$ to afford white solid product 4 (975 mg, 76\%). $\quad R_{f}=0.47 \quad(1: 12$ $\mathrm{MeOH} / \mathrm{CH}_{2} \mathrm{Cl}_{2}$ ), mp 173-175 ${ }^{\circ} \mathrm{C}$. ${ }^{1} \mathrm{H}$ NMR (acetone$\left.\mathrm{d}_{6}\right): \delta 2.10-2.19\left(\mathrm{~m}, 2 \mathrm{H}, \mathrm{CH}_{2}\right), 2.23-2.28(\mathrm{~m}, 1 \mathrm{H}$, $\mathrm{CH}), 2.44-2.49$ (m, 1H, CH), 4.23-4.25 (m, 1H, CH), 4.55-4.65 (m, 2H, CH 2$), 7.07$ (br s, $1 \mathrm{H}, \mathrm{NH}), 7.51$ (t, $J$ $=8.0 \mathrm{~Hz}, 1 \mathrm{H}, \mathrm{Ph}-\mathrm{H}), 7.73(\mathrm{t}, J=7.5 \mathrm{~Hz}, 2 \mathrm{H}, \mathrm{Ph}-\mathrm{H})$, 8.00 (br s, $1 \mathrm{H}, \mathrm{NH}) .{ }^{13} \mathrm{C}$ NMR (acetone- $\mathrm{d}_{6}$ ): $\delta 26.65$, 29.84, 41.36, 57.34, $123.07\left(\mathrm{q}, J_{C-F}=270.8 \mathrm{~Hz}, \mathrm{CF}_{3}\right)$, $127.28\left(\mathrm{q}, J_{C-F}=5.5 \mathrm{~Hz}\right), 128.08,128.79\left(\mathrm{q}, J_{C-F}=\right.$ $30.6 \mathrm{~Hz}), 131.34,133.84,140.21,173.80,178.43$. MS (ESI): $321\left([\mathrm{M}+\mathrm{H}]^{+}, 100 \%\right)$. HRMS (ESI): calcd for $\mathrm{C}_{13} \mathrm{H}_{12} \mathrm{~N}_{2} \mathrm{O}_{2} \mathrm{ClF}_{3} \mathrm{Na} \quad\left([\mathrm{M}+\mathrm{Na}]^{+}\right)$343.0437, found 343.0432 .

(f) tert-Butyl (S)-(2-chloro-3(trifluoromethyl)benzyl)(5-oxopyrrolidine-2-

carbonyl)carbamate (Boc-protected desmethylGSK1482160, 5): Compound 4 (300 mg, $0.93 \mathrm{mmol})$ and $(\mathrm{Boc})_{2} \mathrm{O}(430 \mathrm{mg}, 1.97 \mathrm{mmol})$ were mixed with DMAP (115 mg, $0.93 \mathrm{mmol}$ ) and $\mathrm{Et}_{3} \mathrm{~N}$ (142 mg, 1.4 $\mathrm{mmol})$ in acetonitrile $(50 \mathrm{~mL})$. The reaction mixture was stirred at RT for $24 \mathrm{~h}$. The resulting mixture was 
concentrated, and the residue was purified by column chromatography on silica gel with eluent $(2: 98$ $\left.\mathrm{MeOH} / \mathrm{CH}_{2} \mathrm{Cl}_{2}\right)$ to give white solid product $5(173 \mathrm{mg}$, 44\%). $R_{f}=0.46\left(1: 19 \mathrm{MeOH} / \mathrm{CH}_{2} \mathrm{Cl}_{2}\right)$, mp 145-147 ${ }^{\circ} \mathrm{C} .{ }^{1} \mathrm{H}$ NMR $\left(\mathrm{CDCl}_{3}\right): \delta 1.39\left(\mathrm{~s}, 9 \mathrm{H}, 3 \times \mathrm{CH}_{3}\right), 2.14-$ $2.20(\mathrm{~m}, 1 \mathrm{H}, \mathrm{CH}), 2.22-2.29(\mathrm{~m}, 1 \mathrm{H}, \mathrm{CH}), 2.43-2.49$ $(\mathrm{m}, 1 \mathrm{H}, \mathrm{CH}), 2.70-2.78(\mathrm{~m}, 1 \mathrm{H}, \mathrm{CH}), 4.53(\mathrm{dd}, J=$ $2.8,7.8 \mathrm{~Hz}, 1 \mathrm{H}, \mathrm{CH}), 4.57-4.67\left(\mathrm{~m}, 2 \mathrm{H}, \mathrm{NCH}_{2}\right), 6.88$ (s, $1 \mathrm{H}, \mathrm{Ph}-\mathrm{H}), 7.34(\mathrm{t}, J=7.5 \mathrm{~Hz}, 1 \mathrm{H}, \mathrm{Ph}-\mathrm{H}), 7.63(\mathrm{~d}$, $J=7.5 \mathrm{~Hz}, 2 \mathrm{H}, \mathrm{Ph}-\mathrm{H}) .{ }^{13} \mathrm{C}$ NMR $\left(\mathrm{CDCl}_{3}\right): \delta 22.08$, $27.82,31.66,41.55,60.17,83.99,121.74\left(\mathrm{q}, J_{C-F}=\right.$ $\left.271.6 \mathrm{~Hz}, \mathrm{CF}_{3}\right), 126.83,126.90\left(\mathrm{q}, J_{C-F}=5.3 \mathrm{~Hz}\right)$, $128.93\left(\mathrm{q}, J_{C-F}=30.9 \mathrm{~Hz}\right), 131.51,133.53,137.90$, 150.03, 171.01, 173.89. MS (ESI): 419 ([M-H] $\left.{ }^{\circ}, 1 \%\right)$. HRMS (ESI): calcd for $\mathrm{C}_{18} \mathrm{H}_{20} \mathrm{~N}_{2} \mathrm{O}_{4} \mathrm{ClF}_{3} \mathrm{Na}\left([\mathrm{M}+\mathrm{Na}]^{+}\right)$ 443.0961, found 443.0972.

(g) tert-Butyl (2-chloro-3(trifluoromethyl)benzyl)carbamate (6): 2-Chloro-3(trifluoromethyl)benzylamine $(210 \mathrm{mg}, 1.0 \mathrm{mmol})$ was dissolved in THF-water (1:1) and then (Boc) $)_{2} \mathrm{O}(229$ $\mathrm{mg}, 1.05 \mathrm{mmol}$ ) was added to the solution. The reaction mixture was stirred at RT for overnight. Then the mixture was concentrated in vacuo, and cooled down. The resulting precipitate was filtered, washed with water, and dried, affording white solid product 6 (278 mg, 90\%). $R_{f}=0.60$ (1:5 EtOAc/hexanes), $\mathrm{mp}$ 98-100 ${ }^{\circ} \mathrm{C} .{ }^{1} \mathrm{H}$ NMR $\left(\mathrm{CDCl}_{3}\right): \delta 1.45\left(\mathrm{~s}, 9 \mathrm{H}, 3 \times \mathrm{CH}_{3}\right)$, $4.45\left(\mathrm{~d}, J=6.0 \mathrm{~Hz}, 2 \mathrm{H}, \mathrm{CH}_{2}\right), 5.05(\mathrm{~s}, 1 \mathrm{H}, \mathrm{NH}), 7.35$ $(\mathrm{t}, J=7.5 \mathrm{~Hz}, 1 \mathrm{H}, \mathrm{Ph}-\mathrm{H}), 7.59(\mathrm{~d}, J=7.5 \mathrm{~Hz}, 1 \mathrm{H}, \mathrm{Ph}-$ H), 7.62 (d, $J=7.5 \mathrm{~Hz}, 1 \mathrm{H}, \mathrm{Ph}-\mathrm{H})$. MS (ESI): 308 ([M-H] $\left.]^{-}, 1 \%\right)$.

(h) tert-Butyl (2-chloro-3(trifluoromethyl)benzyl)(methyl)carbamate (7): Sodium hydride (60\% dispersion in mineral oil, 152 $\mathrm{mg}, 3.8 \mathrm{mmol}$ ) was added dropwise into a solution of compound $6(588 \mathrm{mg}, 1.9 \mathrm{mmol})$ in THF $(60 \mathrm{~mL})$ at 0 ${ }^{\circ} \mathrm{C}$. After $30 \mathrm{~min}$ methyl iodide $(809 \mathrm{mg}, 5.7 \mathrm{mmol})$ was added. The mixture was reacted at RT for $3 \mathrm{~h}$. The reaction mixture was concentrated in vacuo, and thereto was added water in an ice bath. Then it was extracted with ethyl acetate, and washed with brine. The organic layer was dried over $\mathrm{Na}_{2} \mathrm{SO}_{4}$ and concentrated. The residue was purified by column chromatography on silica gel with eluent (10:90 EtOAc/hexanes) to give colorless oily product 7 (559 $\mathrm{mg}, 91 \%) . R_{f}=0.63$ (1:5 EtOAc/hexanes). ${ }^{1} \mathrm{H}$ NMR $\left(\mathrm{CDCl}_{3}\right): \delta 1.41$ and $1.50\left(\mathrm{~s}, 9 \mathrm{H}, 3 \times \mathrm{CH}_{3}\right), 2.89$ and $2.92\left(\mathrm{~s}, 3 \mathrm{H}, \mathrm{NCH}_{3}\right), 4.57$ and $4.62\left(\mathrm{~s}, 2 \mathrm{H}, \mathrm{CH}_{2}\right), 7.36$ (d, $J=7.0 \mathrm{~Hz}, 2 \mathrm{H}, \mathrm{Ph}-\mathrm{H}), 7.62$ (s, 1H, Ph-H).

(i) 1-(2-Chloro-3-(trifluoromethyl)phenyl)- $\mathrm{N}$ methylmethanamine (8): Compound 7 (485 $\mathrm{mg}, 1.5$ mmol) with TFA $(1.0 \mathrm{~mL})$ was dissolved in $\mathrm{CH}_{2} \mathrm{Cl}_{2}$ $(10 \mathrm{~mL})$ at RT. After stirring for $3 \mathrm{~h}$, the solvent was removed, and the residue was dissolved in ethyl acetate, which was washed with aqueous $\mathrm{Na}_{2} \mathrm{CO}_{3}$ followed by brine. The organic layer was dried over $\mathrm{Na}_{2} \mathrm{SO}_{4}$ and concentrated. The residue was purified by column chromatography on silica gel with eluent (2:98 $\mathrm{MeOH} / \mathrm{CH}_{2} \mathrm{Cl}_{2}$ ) to afford yellowish oily product 8
(305 mg, 91\%). $R_{f}=0.52\left(1: 9 \mathrm{MeOH} / \mathrm{CH}_{2} \mathrm{Cl}_{2}\right) .{ }^{1} \mathrm{H}$ NMR $\left(\mathrm{CDCl}_{3}\right): \delta 2.48\left(\mathrm{~s}, 3 \mathrm{H}, \mathrm{NCH}_{3}\right), 3.91(\mathrm{~s}, 2 \mathrm{H}$, $\mathrm{CH}_{2}$ ), 7.35 (t, $\left.J=8.0 \mathrm{~Hz}, 1 \mathrm{H}, \mathrm{Ph}-\mathrm{H}\right), 7.6$ (d, $J=8.0$ $\mathrm{Hz}, 2 \mathrm{H}, \mathrm{Ph}-\mathrm{H})$. MS (ESI): $224\left([\mathrm{M}+\mathrm{H}]^{+}, 100 \%\right)$.

(j) (S)-N-(2-Chloro-3-(trifluoromethyl)benzyl)- $N$ methyl-5-oxopyrrolidine-2-carboxamide

(GSK1482160 isomer, 9): This compound was prepared from compound $\mathbf{8}$ and $L$-pyroglutamic acid using similar procedure for the preparation of compound 3, affording white solid product 9 in $78 \%$ yield. $R_{f}=0.64\left(1: 9 \mathrm{MeOH} / \mathrm{CH}_{2} \mathrm{Cl}_{2}\right) .{ }^{1} \mathrm{H} \quad \mathrm{NMR}$ (acetone- $\mathrm{d}_{6}$ ): $\delta 2.09-2.28\left(\mathrm{~m}, 3 \mathrm{H}, \mathrm{CH}_{2}\right.$ and $\left.\mathrm{CH}\right), 2.24-$ $2.54(\mathrm{~m}, 1 \mathrm{H}, \mathrm{CH}), 2.96$ and $3.19\left(\mathrm{~s}, 3 \mathrm{H}, \mathrm{NCH}_{3}\right), 4.57-$ $4.86\left(\mathrm{~m}, 3 \mathrm{H}, \mathrm{CH}_{2}\right.$ and $\left.\mathrm{CH}\right), 7.00$ and $7.07(\mathrm{~s} 1 \mathrm{H}, \mathrm{Ph}-$ $\mathrm{H})$, 7.51-7.63 (m, 1H, Ph-H), 7.74-7.82 (m, 1H, PhH). MS (ESI): $335\left([\mathrm{M}+\mathrm{H}]^{+}, 100 \%\right)$; MS (ESI): 333 ([M-H], $6 \%)$.

(k) (S)-N-(2-Chloro-3-(trifluoromethyl)benzyl)-1${ }^{11}$ C]methyl-5-oxopyrrolidine-2-carboxamide,

$\left(\left[{ }^{11} \mathrm{C}\right] G S K 1482160, \quad\left[{ }^{11} \mathrm{C}\right] 3\right.$ ): Method A (from desmethyl-GSK1482160, 4). $\left[{ }^{11} \mathrm{C}\right] \mathrm{CO}_{2}$ was produced by the ${ }^{14} \mathrm{~N}(\mathrm{p}, \alpha){ }^{11} \mathrm{C}$ nuclear reaction in the small volume $\left(9.5 \mathrm{~cm}^{3}\right)$ aluminum gas target provided with the Siemens RDS-111 Eclipse cyclotron. The target gas consisted of $1 \%$ oxygen in nitrogen purchased as a specialty gas from Praxair, Indianapolis, IN. Typical irradiations used for the development were $55 \mu \mathrm{A}$ beam current and $30 \mathrm{~min}$ on target. The production run produced approximately $45.5 \mathrm{GBq}$ of $\left[{ }^{11} \mathrm{C}^{-C_{2}}\right.$ at EOB. In a small reaction vial $(5 \mathrm{~mL})$, the precursor 4 (0.3-0.5 mg) was dissolved in $\mathrm{CH}_{3} \mathrm{CN}(500 \mu \mathrm{L})$. To this solution was added $\mathrm{NaH}(1 \mathrm{mg})$. No carrier-added (high specific activity) $\left[{ }^{11} \mathrm{C}_{\mathrm{CH}_{3}} \mathrm{OTf}\right.$ that was produced by the gas-phase production method ${ }^{28}$ from $\left[{ }^{11} \mathrm{C}_{\mathrm{CO}_{2}}\right.$ through $\left[{ }^{11} \mathrm{C}\right] \mathrm{CH}_{4}$ and $\left[{ }^{11} \mathrm{C}\right] \mathrm{CH}_{3} \mathrm{Br}$ with silver triflate (AgOTf) column was passed into the reaction vial at $\mathrm{RT}$, until radioactivity reached a maximum ( $2 \mathrm{~min})$, and then the reaction vial was isolated and heated at $80{ }^{\circ} \mathrm{C}$ for $3 \mathrm{~min}$. The contents of the reaction vial were diluted with $\mathrm{NaHCO}_{3}$ solution $(0.1 \mathrm{M}, 1 \mathrm{~mL})$, and injected onto the semi-preparative RP HPLC column with $3 \mathrm{~mL}$ injection loop for purification. The product fraction was collected in a recovery vial containing $30 \mathrm{~mL}$ water. The diluted tracer solution was then passed through a C-18 SepPak Plus cartridge, and washed with water $(5 \mathrm{~mL} \times 4)$. The cartridge was eluted with EtOH $(1 \mathrm{~mL} \times 2)$, followed by $10 \mathrm{~mL}$ saline, to release $\left[{ }^{11} \mathrm{C}\right] 3$. The eluted product was then sterile-filtered through a sterile vented Millex-FG $0.2 \mu \mathrm{m}$ filter, and collected into a sterile vial. Total radioactivity (4.6-8.2 GBq) was assayed and total volume (10-11 mL) was noted for tracer dose dispensing. The overall synthesis, purification and formulation time was 30-40 min from EOB. Retention times in the analytical HPLC system were: $t_{R} \mathbf{4}=2.84 \mathrm{~min}, t_{R} \mathbf{3}=4.39 \mathrm{~min}, \mathrm{t}_{\mathrm{R}} \mathbf{9}=3.56$ $\mathrm{min}, \mathrm{t}_{\mathrm{R}}\left[{ }^{11} \mathrm{C}\right] \mathbf{3}=4.41 \mathrm{~min}$, and $\mathrm{t}_{\mathrm{R}}\left[{ }^{11} \mathrm{C}\right] \mathbf{9}=3.60 \mathrm{~min}$. Retention times in the semi-preparative HPLC system 
were: $t_{R} \mathbf{4}=3.63 \mathrm{~min}, t_{R} \mathbf{3}=7.13 \mathrm{~min}, \mathrm{t}_{R} \mathbf{9}=5.68$ $\min , t_{R}\left[{ }^{11} \mathrm{C}\right] 3=7.21 \mathrm{~min}$, and $t_{R}\left[{ }^{11} \mathrm{C}\right] \mathbf{9}=5.79 \mathrm{~min}$. The radiochemical yield of $\left[{ }^{11} \mathrm{C}\right] \mathbf{3}$ was $40-50 \%$ decay corrected to $\mathrm{EOB}$, based on $\left[{ }^{11} \mathrm{C}\right] \mathrm{CO}_{2}$. Method $\mathrm{B}$ (from Boc-protected desmethyl-GSK1482160, 5). The precursor $5(0.3-0.5 \mathrm{mg})$ was dissolved in DMSO (500 $\mu \mathrm{L}$ ) in a $5-\mathrm{mL} \mathrm{V}$-vial. To this solution was added dry $\mathrm{K}_{2} \mathrm{CO}_{3}$ powder $(1 \mathrm{mg})$. $\left[{ }^{11} \mathrm{C}\right] \mathrm{CH}_{3} \mathrm{OTf}$ was passed into the reaction vial at $\mathrm{RT}$ until radioactivity reached a maximum ( $2 \mathrm{~min})$, and then the reaction vial was isolated and heated at $100{ }^{\circ} \mathrm{C}$ for $5 \mathrm{~min}$ to form a radiolabeled intermediate Boc-protected $\left[{ }^{11} \mathrm{C}\right]$ GSK 1482160 . Then, a solution of $1 \mathrm{~N} \mathrm{HCl}(500$ $\mu \mathrm{L}$ ) was introduced to the reaction vial. The reaction mixture was sealed and heated at $100{ }^{\circ} \mathrm{C}$ for $3 \mathrm{~min}$. The contents of the reaction vial were diluted with $\mathrm{NaHCO}_{3}(0.1 \mathrm{M}, 1 \mathrm{~mL})$, and injected onto the semipreparative HPLC column with $3 \mathrm{~mL}$ injection loop for purification. The purification and formulation procedures were same with Method A. The overall synthesis, purification and formulation time was $~ 40$ min from EOB. Retention times in the analytical HPLC system were: $t_{R} \mathbf{5}=5.27 \mathrm{~min}, \mathrm{t}_{\mathrm{R}} \mathbf{3}=4.39 \mathrm{~min}$, and $t_{R}\left[{ }^{11} \mathrm{C}\right] 3=4.41 \mathrm{~min}$. Retention times in the semipreparative HPLC system were: $t_{R} \mathbf{5}=8.92 \mathrm{~min}, \mathrm{t}_{\mathrm{R}} \mathbf{3}=$ $7.13 \mathrm{~min}$, and $\mathrm{t}_{\mathrm{R}}\left[{ }^{11} \mathrm{C}\right] \mathbf{3}=7.21 \mathrm{~min}$. The decay corrected radiochemical yields were $30-40 \%$. 